Available Online at : journal.stieamkop.ac.id/seiko

"VOL 3, NO 1 (2019): July - Desember"

\begin{tabular}{|c|c|}
\hline \multirow{2}{*}{$20150 \begin{array}{l}\text { ISSN:2598-831X(Print) } \\
\text { ISSN:2598-8301(Online) }\end{array}$} & \\
\hline & SEIKO \\
\hline \multicolumn{2}{|l|}{ Journal of Management \& Business } \\
\hline $\begin{array}{l}\text { Is a peer-reviewed journal published by } \\
\text { Program Pascasarjana STIE Amkop Makassar }\end{array}$ & 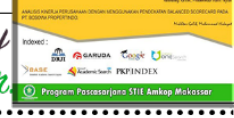 \\
\hline $\begin{array}{l}\text { How to Cite: } \\
\text { M.Rusydi., Naidah, S.Sulaiman (2019). THE ROLE OF I } \\
\text { CAPABILITY IN IMPROVING EXPORT COI } \\
\text { COMPETITIVENESS AND PERFORMANCE. SEIKO : J } \\
\text { Management \& Business, } 3(1), 83-100 .\end{array}$ & $\begin{array}{l}\text { DYNAMIC } \\
\text { MPANIES' } \\
\text { Journal of }\end{array}$ \\
\hline
\end{tabular}

\title{
THE ROLE OF DYNAMIC CAPABILITY IN IMPROVING EXPORT COMPANIES' COMPETITIVENESS AND PERFORMANCE
}

\author{
Muhammad Rusydi \\ Universitas Muhammadiyah Makassar \\ Email: rusydi@unismuh.ac.id \\ Naidah \\ Universitas Muhammadiyah Makassar \\ Email : naida@unismuh.ac.id \\ Syarifuddin Sulaiman \\ Universitas Muhammadiyah Makassar \\ Email : syarif@unismuh.ac.id
}


Available Online at : journal.stieamkop.ac.id/seiko

"VOL 3, NO 1 (2019): July - Desember"

\begin{abstract}
Business competition at the international level is an important issue for companies, this is due to various different motives. This study aimed to identify and analyze the level of influence of dynamic capabilities on competitiveness and export performance. This research was conducted on export companies in South Sulawesi, Indonesia. The population in this study were the managers of each company, the sampling technique with sampling census so that the entire population was also a research sample. The main data collection was done by distributing questionnaires to the respondents. Secondary data in the form of export performance reports and other reports from BPS, the Department of Industry and Trade of the South Sulawesi Provincial Government, and PT Pelabuhan Indonesia IV (Persero). The analysis technique in this study deployed the Structural Equation Model.

The results of the study shown that increasing dynamic capability had a positive and significant effect on increasing competitiveness in export companies, thus all dimensions in dynamic capability had a strategic contribution to the variable competitiveness. Competitiveness variables had a positive and significant effect on export performance in South Sulawesi. Increasing the competitiveness of export companies had an impact on increasing export performance. Dynamic capability variables had no significant effect on export performance. The originality in this study is the application of export performance models that establish dynamic capabilities as external factors, and then explain the role of dynamic capabilities on export performance through competitiveness. For practitioners, dynamic capability is an external factor which is very important in influencing competitiveness. Therefore export companies should be focus and maximize the role of dynamic capability as a macro factor that encourages increased export performance.
\end{abstract}

Keywords: Dynamic Capability, competitiveness, performance, export, and strategy

\title{
INTRODUCTION
}

The discussion of international competition is a complex topic, especially related to the correct and effective export strategy on the international market. In general, companies have a tendency to compete in international markets by considering certain types of strategies and their impact on company operations ( $\mathrm{Ju}$ et al. 2014). The company is in a dynamic and turbulent environment, this is indicated by intense competition, uncertain market conditions, fast technological 
Available Online at : journal.stieamkop.ac.id/seiko

"VOL 3, NO 1 (2019): July - Desember"

changes. This condition makes the factors that influence the success of products on the international market an important factor for the survival and growth of the company. The development of new commodities or products that are effective and in accordance with market needs, is a challenging task for exporters. Some previous studies stated that determining the best strategy is the main determinant of the success or failure of commodity or product innovations (Hajipour \& Gholamzadeh, 2010). Some researchers assess that whatever the motives of companies to enter foreign markets, increasing export performance is a major concern (Stoian et al. 2012). The company is faced with the increasing global competition on market expanding, the company can adjust its strategy and change the organizational structure to improve competitiveness.

Export performance is a fundamental problem in strategic management and international marketing research (Morgan et al. 2012). The problem of the export performance concept requires an accurate and effective understanding of the importance of international strategies and export performance in the face of increasingly global world markets. International marketing research has an important role in explaining the phenomenon of exporters and non-exporters as well as explaining related performance (Jelodarloo et al. 2013). In today's complex business world, performance is needed for every company to analyze success rates, both at the domestic and international level. Performance as a level of the company's objectives both economically and strategy in exporting its products to foreign markets, which achieved through planning and implementing export strategies. According to Fuchs \& Köstner, (2015) in the current condition of global business activities performance is a guide used by companies to analyze the level of success in the country and in the international environment. The export performance of the company reflects the specific behavior of the company in utilizing and managing resources and capabilities effectively in the context of international competition. Performance as a phenomenon that becomes a comprehensive and specific 
Available Online at : journal.stieamkop.ac.id/seiko

"VOL 3, NO 1 (2019): July - Desember"

empirical study examines the factors associated with improving performance. Various previous studies related to providing a better understanding of company factors that influence the success of company exports.

Obstacles experienced by export companies both internally and externally, then Makhmutova \& Mustafin (2017) suggests five key management actions that can be used to minimize barriers to international trade including (1) embodying; (2) Superior in management (superior management) in this case the development of strategic alliances; (3) Customizing, developing features or values that have the highest benefits so that customers will pay a higher price; (4) Technology, using communication and computer technology; (5) Micromarketing, by working with the government to overcome export barriers through government regulations. The success of export activities that can be seen through export performance is inseparable from the factors that influence the performance, Carneiro et al. (2011) try to classify things that affect export performance into two parts, namely internal factors and external factors, which based on resource theory as an internal factor and organizational theory as an external factor. While industry organization theory argues that external factors that influence strategy, logically is an external environment where each company must be able to adjust to survive.

This is an urgent problem as the most competitive organization when simultaneously meeting the goals of global efficiency. This is the company's most competitive challenge when they simultaneously meet the objectives of global efficiency and local response. Export performance can be seen through, export revenues, export revenues growth and export profitability (Carneirol et al. 2011). Factors that influence export performance according to Carneirol et al. (2011) are economic, market, and performance strategy. The challenges of companies in competing in the international market are not solely determined by export performance factors, but competitiveness is also an important determinant of the company. The concept of competing strategies has been widely adopted by various 
Available Online at : journal.stieamkop.ac.id/seiko

"VOL 3, NO 1 (2019): July - Desember"

service and non-service companies (Voola \& O'Cass, 2010). Strategies to compete not only for large companies that already have a good reputation, small and mediumsized companies also should adopt this strategy. Yet in reality the industry is always dynamic and always evolves.

Future uncertainties and various potential threats and challenges in a growing business environment (Hitt et al. 2015). Competitive advantage is obtained when a company develops or acquires attributes (or carries out actions) that allow it to outperform its competitors. The development of theories helps explain the competitive advantage that has become a concern of managers. Organizational capability is one of the important internal factors in managing the resources that the organization already has so that the company able to achieve competitive advantage. When the capabilities in the organization are good, the management of resources will be better, especially when the organization's resources are good and will be able to achieve competitive advantage. Organizational capability is understood as the ability of an organization to carry out its tasks or activities in a coordinated manner to achieve its objectives, which according to Rastislav \& Silvia (2015) consists of individual and team capabilities. Rastislav \& Silvia (2015) organizational capability is the main source for achieving good corporate performance and the application of whether or not capabilities depend on available resources (Giniuniene \& Jurksiene, 2015). The resources owned by the company are not good, so the company will have difficulty managing those resources and therefore its capabilities will not be optimal. With the company's ability to manage all its resources, the company's performance will increase. This is reinforced by the statement of several researchers who stated that when a company is able to identify, develop and use and maintain its resources that are different from its competitors, this will make the company able to maintain ownership of its competitive advantage.

The importance of company capability as an antecedent of competitive advantage which is the creator of organizational performance is possible because 
Available Online at : journal.stieamkop.ac.id/seiko

"VOL 3, NO 1 (2019): July - Desember"

capability has two connotative meanings (Banerjee et al. 2018), namely (1) intentionality, where capability is defined as the ability of managers to use existing means to achieve company goals. The meaning of capability intentionality is more as the manager's ability to integrate; (2) reliability, where capability is defined as the ability of managers to use their capabilities more than once: the ability of managers to manage routine tasks needed to produce quality products in accordance with market desires. Technological advances, economic restructuring, and public demands for better products and services have forced companies to reconsider their business strategies in achieving sustainable competitive advantage (Alzawahreh \& Khasawneh, 2011). The condition of overall change in the business world causes competitiveness as a major factor for the life of the company (Hemmatfar, Salehi, \& Bayat, 2010). To survive and thrive in a rapidly changing environment, companies must consistently use different types and levels of strategies to be more competitive and profitable (Teeratansirikool et al. 2013).

Competitiveness strategy, companies generally expand product lines by standardizing and sharing technology (Mohsenzadeh \& Ahmadian, 2016). Pulaj et al (2015) in his research stated that the types of Porter generic strategies and cost leadership strategies have an impact on improving performance. While the study of Asdemir et al. (2013) explained that companies have high value if implementing differentiation strategies compared to cost leadership strategies. This study aims to identify and analyze the level of influence of dynamic capabilities on competitiveness and export performance.

\section{LITERATURE STUDY}

\section{Dynamic capability, competitiveness and export performance}

Previous studies in international marketing have explained the importance of understanding the relationship between dynamic capabilities and strategic competitiveness and export performance. Referring to the dynamic capability theory 


\section{Available Online at : journal.stieamkop.ac.id/seiko}

"VOL 3, NO 1 (2019): July - Desember"

(Jang, 2013), company performance is determined by the company's ability to obtain and use resources to adapt to their business environment (Bleady et al. 2018). The company's ability consists of complex coordination and unique knowledge that becomes an important capital for management in managing the company well.

Export companies are important to understand the role of dynamic capabilities in the context of global marketing. Many previous studies explained the impact of dynamic capabilities on strategic competitiveness and export performance. Dynamic capability approach to emphasize the benefits of specific internal and external company competencies to overcome environmental change. The element of this approach is explained by experts such as Hareebin et al. (2018): because the dynamic capability approach emphasizes the development of management capabilities, and improves organizational, functional and technological skills.

Dynamic capability has the ability to integrate, product development, technology transfer, intellectual property, manufacturing, human resources, and organizational learning. Dynamic capability as a strategic approach that is better than other traditional strategies. Dynamic capability as an approach that is considered new and has the opportunity to understand the management of sources of competitive advantage. Based on the description, the hypothesis is formulated as follows.

H1: Dynamic capability has a positive and significant effect on competitiveness

H2: Dynamic capability has a positive and significant effect on export performance

\section{Competitiveness and export performance}

The influence of strategic competitiveness on export performance is based on the theory developed by Porter's (Tanwar, 2013) that companies with clear strategies are superior to companies that do not have a strategy. This is the basis of 
Available Online at : journal.stieamkop.ac.id/seiko

“VOL 3, NO 1 (2019): July - Desember"

the theory of strategic competitiveness. Based on the literature review strategy explains three important conditions for the success of the company in achieving a competitive position and is able to support performance improvement. Porter (Valipour et al. 2012) states that strategic competitiveness consists of cost leadership, product differentiation, and focused, non-complementary strategies.

The strategy approach is the most important variable related to export performance. Brouthers et al. (2009) provide support to explain the importance of a strategic approach to export performance. When a company improves strategic competitiveness when exporting it enable the company to compete effectively with its competitors at the global level. Competitiveness refers to rapid business changes where the position of the company has fierce competition against other export companies.

Export performance explains the extent to which the company aims (strategic objectives and economic goals) to export commodities through the design and implementation of export marketing strategies. Kabagambe (2012) explains that export performance is measured by a) increasing competition at the international level, b) strategic position, and c) increasing global market share. Financial export performance is measured by a) profitability, b) increase in stock sales, and c) rapid growth. Based on the description, the hypothesis is formulated as follows.

H3: Competitiveness has a positive and significant effect on export performance

\section{METHODOLOGY}

The design of this study used survey research that took samples from the population and uses questionnaires as a tool for collecting basic data so that through quantitative methods provides a broader understanding of research problems. The initial stage of research design referred to the purpose of the research which was quantitative research. Data collection was done using primary and secondary data. 


\section{Available Online at : journal.stieamkop.ac.id/seiko}

"VOL 3, NO 1 (2019): July - Desember"

Primary data through surveys was conducted using a closed questionnaire. This research questionnaire contained questions based on variables and measurement indicators in accordance with empirical references. The location of the study was conducted in 102 companies in South Sulawesi. Secondary data was coming from from the Department of Industry and Trade of the South Sulawesi Provincial Government, and PT. Pelabuhan Indonesia IV (Persero), the data was in the form of complete data regarding the number of export companies complete with addresses and contact numbers.

The population in this study were managers in each company, sampling techniques with sampling census so that the entire population at the same time became the research sample. The number of samples in this study referred to the number of managers in export companies (source data: each company), namely 231 managers. Identification of respondents was done by: (a) directly visiting the exporter company, (b) through their representatives who are carrying out export commodity shipments at PT. Pelabuhan Indonesia IV (Persero). The scale used in this study was the Likert scale aimed at measuring attitudes, and respondents' views about dynamic capabilities, competitiveness, and export performance. The analysis technique used was the analysis of the Structural Equation Model to measure the level of influence between exogenous and endogenous variables, and the correlation and influence between the latent variables studied. The conceptual framework between variables was illustrated in figure 1 below.

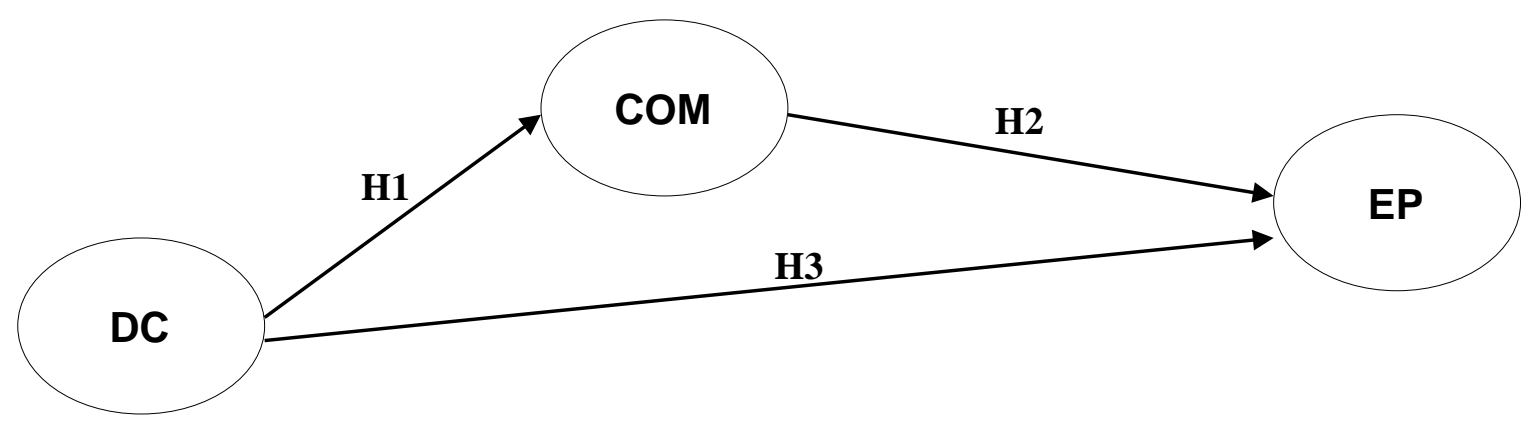


Available Online at : journal.stieamkop.ac.id/seiko

"VOL 3, NO 1 (2019): July - Desember"

Figure 1. Research Conceptual Framework

Information:

DC = Dynamic capability

COM = Competitiveness

$\mathrm{EK}=$ Export performance

\section{FINDINGS AND DISCUSSION}

\section{Profile of Respondents}

The distribution of research questionnaires was carried out in several categories of companies based on export commodities, these categories were (a) animal products, (b) vegetable products, (c) plastic, rubber and similar goods, (d) wood and wood products, and (e ) animal oil and fat. Questionnaires distributed as many as 231 (managers), 175 questionnaires were declared valid and could be analyzed further. Descriptions of respondents are described in table 1 below.

Table 1. Description of respondents

\begin{tabular}{lllll}
\hline Profile & Category & Frequency & $\%$ \\
\hline Gender & Man & 174 & 99,43 \\
\cline { 2 - 4 } & Women & 1 & 0,57 \\
\hline Age of Company & $<5$ years & 13 & 7,43 \\
\cline { 2 - 4 } & $>6$ years & 162 & 92,57 \\
\hline A category & Animal products & 40 & 22,86 \\
companies based on & Vegetable products & 58 & 33,14 \\
commodities & Plastic, rubber, and similar & 26 & 14,86 \\
\cline { 2 - 4 } & items & & \\
\hline
\end{tabular}


Available Online at : journal.stieamkop.ac.id/seiko

"VOL 3, NO 1 (2019): July - Desember"

\begin{tabular}{lll} 
Wood and wood products & 22 & 12,57 \\
\hline Animal oil and fat & 29 & 16,57
\end{tabular}

Table 1 provided information about the profile of respondents involved in this study. Profile on gender, it is found that the number of men is more involved in the export-import business in South Sulawesi. Based on the age of the company it is known that the majority of companies have carried out export activities for more than 6 years. Respondents from vegetable product exporters were most participated in this study.

\section{Data Normality}

Assumptions in the form of identification of skewness values, if in column c.r the scores $>2.58$ or $<-2.58$ (normality of distribution at alpha 1 percent) there was evidence that the data distribution was not normal. Conversely if the value of c.r was below 2.58 or greater than -2.58 then the data was normally distributed. The results of the analysis shown that all research indicator items were declared normal. This research model can be processed and analyzed at the next stage.

\section{Multivariate Outliers}

Based on Chi-Square at 10 degrees of freedom at the significance level of 0.001 or $(0.001: 10)=23,209$. Based on the results of the analysis show that the entire observation number is out of multivariate outliers. The maximum observation number is 51,740 , and the lowest value is 37,428 .

\section{Confirmatory Factor Analysis (CFA)}

The results of the analysis show that all variables (dynamic capability, competitiveness, and export performance) have a value of a loading factor of more than 0.40. This indicates that all dimensions that make up the exogenous and 
endogenous variables are all declared valid and reliable with a level of internal consistency that is in accordance with the standard, so that it is feasible to be tested at a later stage.

\section{Structural Equation Model}

The results of the analysis show that the model has been accepted and meets the SEM criteria. The next stage of analysis is to identify the magnitude of the effect of exogenous variables on endogenous variables. The results of structural equation modeling analysis can be presented as follows.

Table 1. Results of Model Estimates

\begin{tabular}{lllll}
\hline Variables correlation & Estimate & \multicolumn{2}{c}{ Standard Error } & \multicolumn{2}{c}{ Critical Ratio P-value } \\
\hline DC $\rightarrow$ COM & $0.161^{\star}$ & 0.075 & $2.153^{\star}$ & $0.031^{\star}$ \\
\hline COM $\rightarrow$ EP & $0.625^{\star}$ & 0.199 & $3.148^{\star}$ & $0.002^{\star}$ \\
\hline DC $\rightarrow$ EP & 0.028 & 0.089 & 0.314 & 0.753
\end{tabular}

Note: *) Significant at the level of $5 \%$ 
"VOL 3, NO 1 (2019): July - Desember"

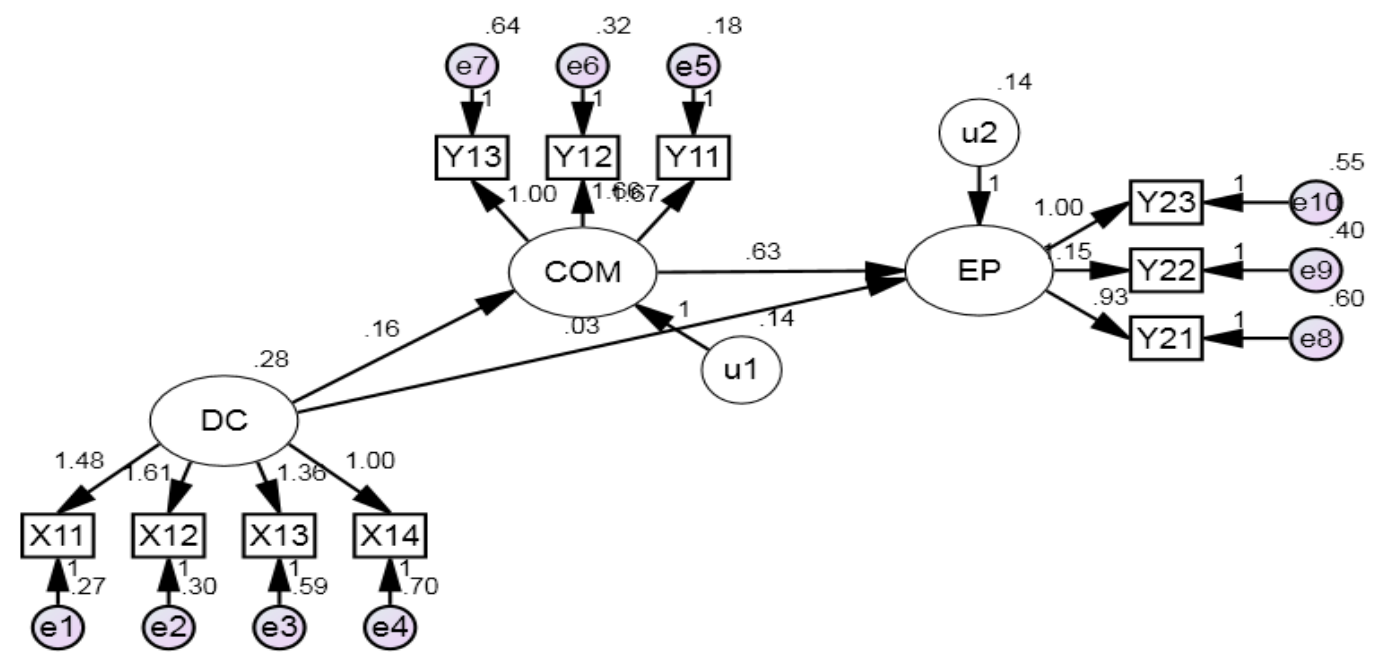

Figure 2. Results of Model Estimates

Based on the results of the analysis in table 2 and figure 2, it shows that dynamic capability has a positive and significant effect on competitiveness, with an increase in dynamic capabilities contributing to increased competitiveness. Thus the first hypothesis is declared accepted. Significant influence between dynamic capabilities on competitiveness explains that if the capabilities in an export company run well, then the management of company resource is better so that it is able to achieve higher competitiveness. Dynamic capability as the ability of export companies to carry out their activities in a coordinated manner to achieve high competitiveness. With the company's ability to manage all its resources, competitiveness increase. If the company is able to identify, develop and use and maintain its resources that are different from its competitors, then this make the company able to maintain and increase ownership of its competitiveness.

Changes in the business environment that are very fast cause many companies difficult to maintain competitive advantage. Conventional business strategies are unable to deal with a dynamic business environment, so business 
Available Online at : journal.stieamkop.ac.id/seiko

"VOL 3, NO 1 (2019): July - Desember"

strategies must change, but in reality new strategies do not always succeed in returning the company's competitive advantage. Changes in the business environment have changed the key industry factors. Superior business strategies generally apply superior capabilities. Facing a dynamic business environment, renewing dynamic capabilities is carried out. Companies not only make internal adjustments but must make changes to their capabilities.

The results of the second analysis explain that competitiveness has a positive and significant effect on export performance. The hypothesis that competitiveness has a significant effect on export performance is stated to be accepted. South Sulawesi's exports are still based on primary products (oil and gas, commodities and primary industries), so as to sustain natural resources, efforts to increase exports through increasing competitiveness through increasing the role of manufactured products. Increasing this role can be done by recruiting special skilled skilled personnel and the use of high-tech requirements in the production process. Deep understanding of the characteristics of export companies aims to help develop strategies, build company competitiveness, and establish effective policies by referring to the theory pioneered by Tanwar (2015), namely competitive advantage theory.

The third analysis results explain that dynamic capabilities do not have a significant effect on export performance, so the second hypothesis is rejected. This is due to the dynamic capabilities applied to export companies that have not been able to anticipate the global economic downturn, so that the export performance in South Sulawesi has for a number of years experienced a significant decline. There has been a shift in global demand for primary commodities, triggered by an uncertain global economy. The dynamic capability of export companies generally requires a strategic step to secure the company from the threats and challenges of the global economy that are slowing down through strengthening entrepreneurial aspects. With creative and innovative processes, companies can face global challenges. 
Available Online at : journal.stieamkop.ac.id/seiko

"VOL 3, NO 1 (2019): July - Desember"

\section{CONCLUSION}

The results of this study show some important results, namely first: dynamic capability variables have a significant effect on competitiveness so that the first hypothesis is declared accepted. The influence between these variables is in accordance with the literature review, as well as the high contribution of all dimensions of the variable dynamic capability and competitiveness. The next results show that competitiveness has a significant effect on export performance, these results prove that the third hypothesis is declared acceptable. The results of the last analysis explained that the second hypothesis was rejected because statistically, the dynamic capability variable had no significant effect on export performance. The originality in this study is the application of export performance models that establish dynamic capabilities as external factors, then explain the role of dynamic capabilities on export performance through competitiveness. For practitioners, dynamic capability is an external factor that is very important in influencing competitiveness. Therefore export companies must focus and maximize the role of dynamic capability as a macro factor that encourages increased export performance.

\section{REFERENCES}

Alzawahreh, A., \& Khasawneh, S. (2011). Business Strategies Adopted by Jordanian Organizations: The Key to Sustained Competitive Advantage. Interdisciplinary Journal of Contemporary Research in Business. Vol. 3. No. 5 , 508-524.

Asdemir O, Fernando GD, Tripathy A. (2013). Market perception of firm strategy. Managerial Finance, Vol. 39 No. 2.

Banerjee, C.S., Ayesha Farooq., and Shivakant Upadhyaya. (2018). The Relationship between Dynamic Capabilities, Competitive Advantage \& Organizational Performance. International Journal of Interdisciplinary Research and Innovations, Vol. 6, Issue 3, pp: 603-610. 
Available Online at : journal.stieamkop.ac.id/seiko

"VOL 3, NO 1 (2019): July - Desember"

Bleady, A., Abdel Hafiez Ali., and Siddig Balal Ibrahim. (2018). Dynamic capabilities theory: pinning down a shifting concept. Academy of Accounting and Financial Studies Journal, Volume 22, Issue 2.

Brouthers, L.E., George Nakos, John Hadjimarcou, and Keith D. Brouthers. (2009). Key Factors for Successful Export Performance for Small Firms. Journal of International Marketing, Vol. 17, No. 3, pp: 21-38.

Carneirol, Jorge., Angela da Rochall., Jorge Ferreira da Silva. (2011). Determinants of export performance: a study of large brazilian manufacturing firms. Braz. Adm. Rev. vol.8 no.2 Curitiba

Fuchs, M., \& M. Köstner. (2015). Standardisation and adaptation of firms' export marketing strategies in familiar European and non-familiar non-European markets. European J. International Management, Vol. 9, No. 3.

Giniuniene, J., and L. Jurksiene. (2015). Dynamic Capabilities, Innovation and Organizational Learning: Interrelations and Impact on Firm Performance. Procedia - Social and Behavioral Sciences, 213, pp: 985 - 991.

Hajipour, B., \& R. Gholamzadeh. (2010). The Effects of Market Entry Strategy Dimensions on the Performance: An Empirical Study of Iranian Food \& Chemical Industries. European Journal of Economics, Finance and Administrative Sciences, Issue 22.

Hareebin, Y., Somnuk Aujirapongpan, and Sununta Siengthai. (2018). Creating sustained strategic capabilities through organisational dynamic capabilities and strategies: a case study of rubber wood export industry in Thailand. Asian Academy of Management Journal, Vol. 23, No. 1, 117-150.

Hemmatfar, M., Salehi, M., \& Bayat, M. (2010). Competitive Advantages and Strategic Information Systems . International Journal of Business and Management. Vol. 5. No. 7, 158-169.

Hitt, M.A., Dan Li., and Kai Xu. (2015). International strategy: from local to global and beyond. Journal of World Business, DOI:10.1016/j.jwb.2015.08.016

Jang, Seung Hoon. (2013). The Offensive Framework of ResourceBased View (RBV): Inhibiting Others from Pursuing Their Own Values. Journal of Management and Strategy, Vol. 4, No. 1. 
Available Online at : journal.stieamkop.ac.id/seiko

"VOL 3, NO 1 (2019): July - Desember"

Jelodarloo, S.N., Zaher Hatami., and Afshar Hatami. (2013). Impact of export marketing strategy on export performance (Case Study: Tabriz). International Journal of Management and Humanity Sciences. Vol. 2 (6), 521-529.

Ju, Min., Hongxin Zhao, and Tiedong Wang. (2014). The Boundary Conditions of Export Relational Governance: A "Strategy Tripod" Perspective. Journal of International Marketing, Vol. 22, No. 2, pp: 89-106.

Kabagambe, L. B. (2012). Firm competencies and export performance: A study of small and medium manufacturing exporters in competencies in Uganda. European Scientific Journal, 48-67.

Makhmutova, D.I., \& Askar N. Mustafin. (2017). Impact of International Trade on Economic Growth. International Journal of Scientific Study, Vol. 5, Issue 6.

Mohsenzadeh, Mohsen., \& Sahar Ahmadian. (2016). The Mediating Role of Competitive Strategies in the Effect of Firm Competencies and Export Performance. Procedia Economics and Finance, 36 pp: 456 - 466.

Morgan, Neil A., Constantine S. Katsikeas., and Douglas W. Vorhies. (2012). Export marketing strategy implementation, export marketing capabilities, and export venture performance. Journal of the Academy of Marketing Science, Vol. 40, No. 2.

Pulaj, E., Vasilika Kume., and Amali Cipi. (2015). The impact of generic competitive strategies on organizational performance. the evidence from albanian context. European Scientific Journal, October 2015 edition, Vol.11, No.28.

Rastislav, R., and L. Silvia. (2015). Strategic Management of Business Performance Based on Innovations and Information Support in Specific Conditions of Slovakia. Journal of Competitiveness, Vol. 7, Issue 1, pp: 3-21.

Stoian, M.C., Alex Rialp., and Josep Rialp. (2012). International marketing strategy and export performance in Spanish SMEs: a contingency approach. International Journal of Entrepreneurship and Small Business, Vol. 15, No. 2.

Tanwar, Ritika. (2013). Porter's Generic Competitive Strategies. IOSR Journal of Business and Management (IOSR-JBM), Volume 15, Issue 1, pp 11-17.

Teeratansirikool, Luliya., Sununta Siengthai, Yuosre Badir, and Chotchai Charoenngam. (2013). Competitive strategies and firm performance: the 
Available Online at : journal.stieamkop.ac.id/seiko

"VOL 3, NO 1 (2019): July - Desember"

mediating role of performance measurement. International Journal of Productivity and Performance Management, Vol. 62 Iss: 2 pp. 168 - 184.

Valipour, H., Hamid Birjandi., and Samira Honarbakhsh. (2012). The Effects of Cost Leadership Strategy and Product Differentiation Strategy on the Performance of Firms. Journal of Asian Business Strategy, 2 (1): 14-23.

Voola, R., \& A. O'Cass. (2010). Implementing competitive strategies: the role of responsive and proactive market orientations. European Journal of Marketing, Vol. 44 Issue: 1/2, pp.245-266. 